\title{
Economizing Phosphorus Use in Groundnut Production by Exploiting Phosphorus Build -Up in Soil
}

\author{
A.H. Kumar Naik ${ }^{1 *}$, N. Pallavi ${ }^{1}$ and N.E. Naveen ${ }^{2}$ \\ ${ }^{1}$ All India Coordinated Research Project on Groundnut, Zonal Agricultural and Horticultural \\ Research Station, Babbur Farm, Hiriyur, Karnataka 577 598, India \\ ${ }^{2}$ Krushi Vigyan Kendra, Brahmavar, Karnataka, India \\ *Corresponding author
}

\begin{tabular}{l} 
K e y w o r d s \\
Groundnut, \\
Phosphorus, \\
Nutrient uptake, \\
Growth and pod \\
yield. \\
Article Info \\
$\begin{array}{l}\text { Accepted: } \\
\text { 04 September } 2017 \\
\text { Available Online: } \\
\text { 10 October } 2017\end{array}$ \\
\hline
\end{tabular}

\section{A B S T R A C T}

The main constraints hampering higher yields and quality of groundnut in Karnataka could be attributed to several production constraints, which may biotic and abiotic stresses include poor and imbalanced nutrition. Therefore, plant nutrition plays a vital role in increasing production and productivity of groundnut. Fertilizer application normally results in increased crop yields up to certain levels. However, the exact time and dose of fertilizer application is also important for successful exploitation of the crop's potentiality in terms of yield. Nowadays it is well established that phosphorus application in groundnut has tremendous impact on growth and development in groundnut and also yield attributes. It is one of the most important strategies particularly in the wake of intense energy crisis, and improvement in fertilizer phosphorus use efficiency in order to exploit the native soil phosphorus for groundnut production. Present investigation consists of 10 treatments sponsored by Directorate of Groundnut Research, Junagadh, Gujarat, conducted at Zonal Agricultural and Horticultural Research station, Hiriyur, Chitradurga District on groundnut, during Kharif 2015-16 on economizing phosphorus use in groundnut production by exploiting phosphorus Build up in the soil. The data revealed that among treatments, $50 \% \mathrm{P}+$ DGRC-2 $(2229 \mathrm{~kg} / \mathrm{ha})$ resulted in increased pod yield of groundnut followed by application of 50\% P + DGRC-1 (2208 kg/ha).

\section{Introduction}

Groundnut or peanut (Arachis hypogaea L.) is an important oilseed crop called as wonder nut and poor men's cashew nut. While being a valuable source of all the nutrients, groundnut plays a vital role in providing an inexpensive source of high quality dietary protein $(26 \%)$ edible oil content in the diets (45-50\%). In addition to protein, it's also a good source of calcium, phosphorus, iron, zinc and boron. It is one of the most important sources of food and cash crop of our country.
This crop is grown over an area of 26.62 million ha spread over 84 countries with an annual production of 35.66 million tones pods with a productivity of $1348 \mathrm{~kg} \mathrm{ha}^{-1}$. In India, it is being grown in 11 states in an area of 4.19 million ha with a production of 5.62 million tones of pods per annum. The average productivity of groundnut in India $(1341 \mathrm{~kg}$ $\mathrm{ha}^{-1}$ ) can be comparable to world average (Anon., 2013). Yield of groundnut is always unpredictable for the major producers the 
average is not only low ( $\mathrm{t} \mathrm{ha} \mathrm{h}^{-1}$ ) but very variable. This is because about $80 \%$ of the world production comes from rainfed areas where rainfall is small and erratic. During its growth and development Groundnut is exposed to various biotic and abiotic stresses, i.e., most sensitive to moisture stress and it is susceptible to a host of diseases and pests which limits the productivity along with factors like declining soil fertility; poor nutrition etc., among major nutrients, Phosphorus is an essential nutrient for crop growth and yield. Although legumes can fix their own nitrogen, they often need phosphorus and potassium for good seed formation (Asiedu et al., 2000).

In groundnut, Phosphorus known to plays important role in increasing root growth, nutrient and water use efficiency and also in enhancing yield. Requirement of phosphorus in modulating legumes is higher when compared to non-modulating crops. Due to the important role played by phosphorus in the physiological processes of plants, application of phosphorus to soil deficient in the nutrient leads to increase groundnut yield.

Phosphorus deficiency is known to reduce flower production, size of pods and adversely affect the formation of root nodules (Seshadri, 1962). The overall improvement in crop growth with $\mathrm{P}$ application seems to be on account of its significant role in early formation of roots, their proliferation and increased microbial activity in the root nodules. This has been shown to improve the effective utilization of soil nutrients by the crop and greater biological $\mathrm{N}$ fixation through enhancement in nitrogenase activity (Venkateswarlu et al., 1988). Therefore this study was planned to examine effect of different doses of phosphorus use in groundnut production by exploiting phosphorus build up in soil and its effect on yield and other yield attributing traits.

\section{Materials and Methods}

An field experiment was conducted on groundnut, during Kharif 2015-16 at Zonal Agricultural and Horticultural Research station, Hiriyur, Chitradurga District on Economizing phosphorus use in groundnut production by exploiting phosphorus build up in the soil with an objective of exploiting the native soil phosphorus for groundnut production which consists of 10 treatments and as follows: T1: Absolute control (No P), T2: 5 t FYM/ha T3: T2 + DGRC 1. T4: T2 + DGRC 2, T5: T2 + 50\% P, T6: T2 + 50\% P + DGRC 1, T7:T2 + 50\% P + DGRC 2, T8: T2 $+100 \%$ P, T9: T2 + 100\% P + DGRC 1, T10:T2 + 100\% P + DGRC 2. The material for the present study comprised of 10 treatments sponsored by Directorate of Groundnut Research, Junagadh, Gujarat. The experiment was laid out in a Randomized Complete Block Design (RCBD), at four replications of different treatments of groundnut with recommended dose of fertilizers (Phosphorus as per treatment and $\mathrm{N}$ and $\mathrm{K}$ as per recommendations) with plot size of 5.0 X4.5m with inter and intra row spacing of $30 \mathrm{~cm}$ and $10 \mathrm{~cm}$. to avoid border effect, one border row plants in all 4 sides of the plot were excluded from the plot yield and yield $\mathrm{kg} / \mathrm{ha}$. During harvest time, five representative plants were collected in net plot randomly from each plot. Data were recorded on $50 \%$ flowering, plant height $(\mathrm{cm})$, plant stand at time of harvesting, number of pods/plant, 100 seed weight $(\mathrm{g})$, shelling percentage $(\%)$, pod yield $(\mathrm{Kg} / \mathrm{ha})$, Kernel yield ( $\mathrm{Kg} / \mathrm{ha})$, etc., All the data on growth, yield and other yield attributes were analyzed statistically.

\section{Results and Discussions}

The pod yield is an end product, which obviously depends upon the total dry matter production at different stages of crop growth 
and its partitioning into reproductive parts for higher production. The data pertaining to yield components namely, 100 Seed weight, Haulm yield/ha, Shelling \%, Kernel yield/ ha and Pod yield $(\mathrm{Kg} / \mathrm{ha})$ did not differ significantly. The experimental results indicated that seed treatments with $50 \% \mathrm{P}+$ DGRC-2 $(2229 \mathrm{~kg} / \mathrm{ha})$ resulted in increased pod yield of groundnut followed by application of 50\% P + DGRC-1 (2208 $\mathrm{kg} / \mathrm{ha})$. The pattern of variation among various treatments with other yield parameters was similar and differences were not significant (Table 1).

As observed in the present study, similar benefits were obtained by Panwar et al., (2006) where effect of phosphorus will induce the uptake ability of roots to nutrients and positive increase in the yield parameters because of improving the root system as a source-sink relationship to the reproductive part (shoot). Further, it is also observed that plant absorbs more water and nutrients from depth of the soil, this in turn could enhance the plant's ability to produce more assimilates which were reflected in the high biomass (Gobarah et al., 2006). As observed in the present study, Khaliq and Sanderz (2000) also observed enhanced phosphorus release increases evaluations for the trait of grain yield, biomass and hundred seed weight.

It has also been reported that photosynthetic gas exchange activity is stimulated through symbiosis with microorganisms in inoculated plants that increases the efficiency of photosynthetic phosphorus.

Table.1 Yield and other yield attributing traits as influenced by different level Phosphorus treatments

\begin{tabular}{|c|c|c|c|c|c|c|c|c|c|c|c|c|}
\hline \multicolumn{2}{|c|}{ Treatments } & \multirow{2}{*}{$\begin{array}{c}\begin{array}{c}\text { Initial } \\
\text { plant } \\
\text { height }\end{array} \\
267\end{array}$} & \multirow{2}{*}{$\begin{array}{c}\begin{array}{c}\text { Final } \\
\text { plant } \\
\text { height }\end{array} \\
257 \\
\end{array}$} & \multirow{2}{*}{$\begin{array}{c}50 \% \\
\text { flowe } \\
\text { ring } \\
31 \\
\end{array}$} & \multirow{2}{*}{$\begin{array}{c}\text { Plant } \\
\text { Height } \\
37\end{array}$} & \multirow{2}{*}{\begin{tabular}{|r}
$\begin{array}{l}\text { Shoot } \\
\text { length }\end{array}$ \\
29.4 \\
\end{tabular}} & \multirow{2}{*}{$\begin{array}{c}\begin{array}{c}\text { No. } \\
\text { of } \\
\text { pods / } \\
\text { Plant }\end{array} \\
23 \\
\end{array}$} & \multirow{2}{*}{$\begin{array}{c}100 \\
\text { seed } \\
\text { weight } \\
(\mathrm{g})\end{array}$} & \multirow{2}{*}{$\begin{array}{c}\text { Shelling } \\
\% \\
71\end{array}$} & \multirow{2}{*}{$\begin{array}{c}\begin{array}{c}\text { Kernel } \\
\text { yield } \\
(\mathrm{Kg} / \mathrm{ha})\end{array} \\
718\end{array}$} & \multirow{2}{*}{ 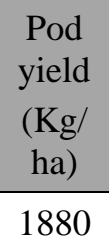 } & \multirow{2}{*}{ 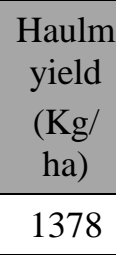 } \\
\hline $\mathrm{T}-1$ & Absolute control (No P) & & & & & & & & & & & \\
\hline $\mathrm{T}-2$ & $5 \mathrm{t} \mathrm{FYM/ha}$ & 286 & 279 & 30 & 37 & 30.6 & 26 & 28.9 & 73 & 790 & 2010 & 1432 \\
\hline $\mathrm{T}-3$ & $\mathrm{~T} 2+\mathrm{DGRC} 1$ & 312 & 315 & 30 & 40 & 31.7 & 30 & 28.0 & 73 & 795 & 1959 & 1470 \\
\hline $\mathrm{T}-4$ & $\mathrm{~T} 2+\mathrm{DGRC} 2$ & 335 & 327 & 28 & 41 & 32.2 & 34 & 27.8 & 73 & 899 & 2131 & 1557 \\
\hline $\mathrm{T}-5$ & $\mathrm{~T} 2+50 \% \mathrm{P}$ & 302 & 293 & 29 & 39 & 31.2 & 29 & 29.2 & 72 & 837 & 2062 & 1486 \\
\hline T-6 & $\mathrm{T} 2+50 \% \mathrm{P}+\mathrm{DGRC} 1$ & 406 & 401 & 29 & 42 & 34.3 & 41 & 30.3 & 75 & 958 & 2208 & 1613 \\
\hline $\mathrm{T}-7$ & $\mathrm{~T} 2+50 \% \mathrm{P}+\mathrm{DGRC} 2$ & 370 & 355 & 28 & 42 & 32.9 & 38 & 29.1 & 74 & 965 & 2229 & 1618 \\
\hline $\mathrm{T}-8$ & $\mathrm{~T} 2+100 \% \mathrm{P}$ & 321 & 306 & 29 & 39 & 32.0 & 32 & 32.4 & 73 & 939 & 2174 & 1604 \\
\hline T-9 & $\mathrm{T} 2+100 \% \mathrm{P}+\mathrm{DGRC} 1$ & 354 & 348 & 30 & 41 & 32.3 & 36 & 30.6 & 75 & 934 & 2151 & 1608 \\
\hline $\mathrm{T}-10$ & $\mathrm{~T} 2+100 \% \mathrm{P}+\mathrm{DGRC} 2$ & 297 & 292 & 29 & 38 & 30.8 & 28 & 30.2 & 77 & 1004 & 1881 & 1600 \\
\hline & SEm \pm & 16.7 & 28.9 & 0.7 & 1.3 & 1.32 & 1.54 & 1.26 & 1.3 & 85.7 & 124.3 & 84.2 \\
\hline & $\mathrm{CD}(\mathrm{P}=0.05)$ & 48.6 & 84.0 & 2.1 & 3.8 & 3.84 & 4.48 & 3.65 & 3.7 & 248 & 360.8 & 244.4 \\
\hline
\end{tabular}

Note: Phosphorus as per treatment and $\mathrm{N} \& \mathrm{~K}$ as per recommendations 


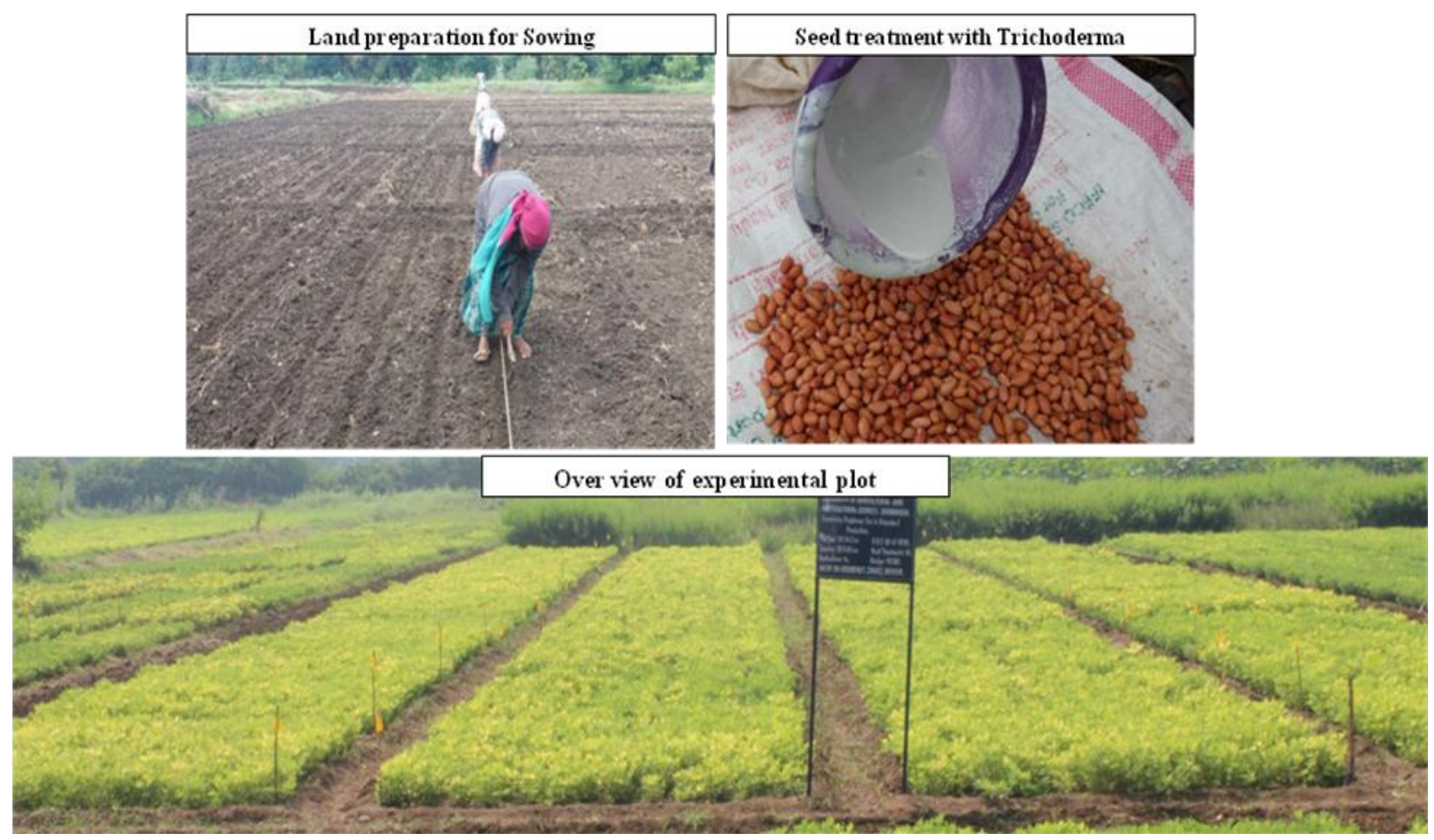

From the present investigation it can be said that though the amount of phosphorus required is less, large quantity of fertilizer has to be applied as the efficiency of phosphorus uptake s very low, because of low phosphorus requirement of groundnut, response to application of phosphatic fertilizers has not been conspicuous, unless available phosphorus level in the soil is low.

The other possible reason for poor response of groundnut to phosphorus application may probably because of the formation of mycorrhizal association of the roots with soil fungi or due to phosphobacteria in the rhizosphere of the plant making unavailable form of phosphorus available to groundnut plant. The variation in pod yield of groundnut could be traced back to variations in yield parameters. The pod yield is governed by a number of factors having direct or indirect influence. Groundnut requires higher amount of nutrients during pegging and pod development stages. Hence, it is feasible, economically viable and environment friendly approach of nutrient management

\section{References}

Anonymous, 2013. Directorate of Economics and Statistics, Govt. of Karnataka.

Asiedu, E.A., Vangastel, A.J.G., and Gregg, B.R., 2000. Extension agents' technical crop guidelines for assisting seed producers in Ghana.

Gobarah, M.E., Mohamed, M.H., and Tawfik, M.M., 2006. Effect of phosphorus fertilizer and foliar spraying with zinc on growth, yield and quality of groundnut under reclaimed sandy soils. J. Appl. Sci. Res. 2(80): 491- 496.

Khaliq, A., and Sanders, F.E., 2000. Effects of vesicular - arbuscularmycrrhizal inoculation on the yield and phosphorus uptake of field - grown barley.Soil Biology and Biochemistry, 32: 16911696.

Panwar, A.S., N.P. Singh, D.C. Saxena, and U.K. Hazarika, 2006. Yield and quality of groundnut seed as influence by phosphorus, biofertilizer and organic manures. Indian Journal of Hill Farming, (CAB abstracts). 
Seshadri, C. R., 1962. Groundnut, a monograph. Indian Central Oilseeds Committee. Hyderabad.

Venkateswarlu, V., Rao, V. V., Rao, A. S. herbicides and $\mathrm{P}$ levels on nodulation $\mathrm{P}$ uptake and yield of urd bean. Indian Journal of Pulses Research, 1(1): 70and Rao, D. S. K., 1988. Effect of

\section{How to cite this article:}

Kumar Naik, A.H., N. Pallavi and Naveen, N.E. 2017. Economizing Phosphorus Use in Groundnut Production by Exploiting Phosphorus Build -Up in Soil. Int.J.Curr.Microbiol.App.Sci. 6(10): 251-255. doi: https://doi.org/10.20546/ijcmas.2017.610.031 